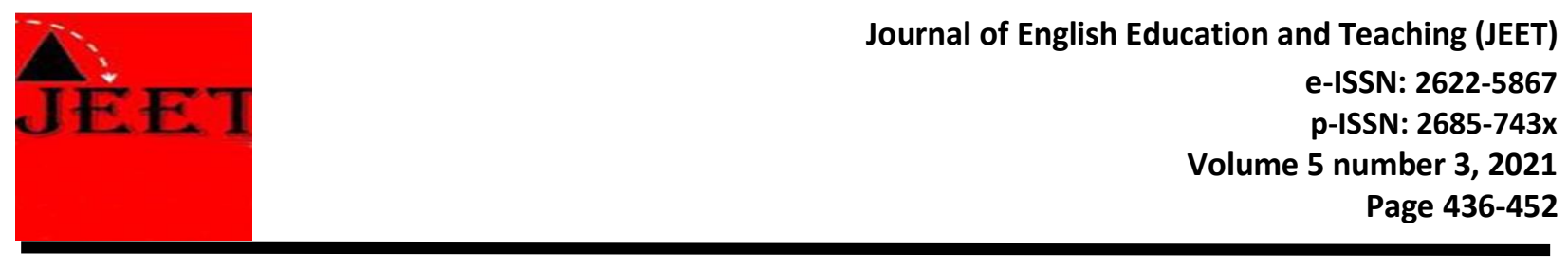

\title{
Investigating English Students' Motivation in Speaking Class during New Normal Era
}

\author{
Feny Martina \\ State Islamic University of Fatmawati Sukarno \\ feny@iainbengkulu.ac.id \\ Ali Akbarjono \\ State Islamic University of Fatmawati Sukarno \\ aliakbarjono@iainbengkulu.ac.id \\ Heny Friantary \\ State Islamic University of Fatmawati Sukarno \\ henyfriantary30@gmail.com \\ Tri Nengsi Puspita Sari \\ Islamic University of Fatmawati Sukarno \\ trinengsipuspita@gmail.com \\ Corresponding email: feny@iainbengkulu.ac.id
}

\begin{abstract}
Motivation is one of the essential factors and dramatically influences the learning process. This study aimed to determine how the level of motivation of students in the speaking class during the new normal era, namely the second-semester students of the English Department of IAIN Bengkulu. This study used a descriptive quantitative approach. The techniques used in collecting data were questionnaires and interviews. The questionnaire consists of 36 questions divided into intrinsic and extrinsic motivation. The data are presented statistically using percentage, frequency, arithmetic mean, and standard deviation division. The results showed that the mean score of intrinsic motivation (3.89) was higher than the average score of extrinsic motivation (3.39). However, the overall motivation average of 3.68 is considered a high level of motivation despite currently studying in the Covid-19 pandemic conditions. The results of this study indicate that the majority of students learn English in the speaking class because of intrinsic motivation. They actively speak and learn English because of their inner desires. Based on the findings of this study, several relevant learning implications and useful motivations are recommended to increase student motivation.
\end{abstract}

Keywords: Learning Motivation (Intrinsic Motivation, Extrinsic Motivation), speaking Class, New Normal Era 


\section{Introduction}

Learning is an activity process to change the behavior of the subject in learning. Changes in behavior can be seen from various forms, including the learning subject being creative. Creativity in learning is characterized by several characteristics such as open thinking and being spontaneous, curious, and independent. Creativity in learning does not just appear but is influenced by several factors, both internal and external. A person will be successful and creative in learning if in himself there is a desire to learn. The desire or urge to learn is what is called motivation. Higher education as one of the educational institutions is responsible for providing quality education to produce graduates who can be highly competitive and answer the challenges of the times. The ideal tertiary institution offers quality and competitive education, in which all systems within the college can run according to its function. (Rusdi, 2013)

In the learning process, motivation has a significant role. Motivation can influence the success or failure of the learning process (Noprianti et.al, 2021). Motivation plays a role in providing encouragement, direction, and persistence in behavior. Motivation can come from within or from the influence of others. Several things need to be considered in teaching and learning interactions (Gross, 2006; Hidayati: 2016), including learning motivation and student concentration both before and when participating in learning. Motivation is regarded as a mental driving force and provides direction for human behavior, including learning behavior. Motivation leads to a desire, hope, a need, and a goal to be achieved. Motivation in the learning process is divided into two, namely intrinsic motivation and extrinsic motivation. What is meant by inherent motivation is the motivation that comes from within a person, while extrinsic motivation is the motivation that comes because external factors influence it.

Students' motivation to learn can be a strength to achieve the best for themselves. Student learning achievement will be optimal if the teacher uses appropriate teaching methods to stimulate student motivation. Teachers must be good at using innovative, active, effective, and comfortable methods in the learning process. The teacher's responsibility is to find the right strategy and make the teaching and learning process effective. Effective teaching strategies include active participation.

However, currently, the teaching and learning process is experiencing challenges due to the Covid-19 virus outbreak. Coronavirus 2019 (Covid-19) is a type of disease that 
is relatively new because it emerged in 2019. This relatively new disease then spread widely throughout the world. It became a barrier to activity for the world because this type of disease had never been identified in humans before(Tria, 2020).

Furthermore, on January 30, WHO declared this disease a dangerous disease and caused the whole world to feel uneasy with this type disease. The Covid-19 pandemic is a problem currently facing the world. The spread of the Covid-19 outbreak also impacts the education sector, which causes a decrease in the quality of learning for students. This pandemic period demands a learning system that is replaced by online learning. Distance learning is implemented so that the learning process continues. Based on this, then the teacher implies learning from home or by online learning.

Before the Covid-19, the learning process was carried out face-to-face. Where students learn in class and come face to face with the lecturer. But with the Covid-19 outbreak, learning methods or habits have changed. When beginning to face or study in class, students can understand better and ask directly what they cannot understand. However, many students admit that they have difficulty following this relatively new learning method when looking online. The most challenging thing is that the atmosphere is not conducive, and there is no teacher assistance. Changes in the learning system certainly significantly affect student learning motivation. In situations like this, students feel bored with learning.

Along with the outbreak of the Covid-19 virus, the government implemented a new normal policy. (Irawan, 2020) To break the chain of spreading the virus that is currently endemic. However, education is still carried out by online or distance learning. This new normal policy also applies to students of IAIN Bengkulu. They carry out lectures by studying at home or learning distance to avoid the spread of Covid-19. The current situation is undoubtedly a challenge for students and lecturers. With the current learning system, of course, learning motivation is needed because students are required to study independently and away from the supervision of lecturers, minimal facilities, and difficulty understanding the current learning system. The reason universities are still learning online and not face-to-face is because students find it easier to learn at a distance compared to other school students.

Then based on interviews with several students in the speaking class, namely the 2nd-semester students of IAIN Bengkulu, on Wednesday, January 13,2020, in the learning 
process in the Speaking class, they admit that they have difficulties in the current learning system. It is due to the lack of conducive learning facilities. It shows that there are still students who are late to class in studying. As well as the lack of English language skills makes them less confident. When the lecturer asked questions, only a few students actively answered and gave ideas or comments. The others only became listeners. As well as the method used by the lecturer is less attractive, so that he feels bored. Therefore, based on the preliminary interviews of researchers on the 3rd-semester students of IAIN Bengkulu, it was found that several problems related to student motivation in the speaking class during the new normal were still low. Therefore, in the present research context, the researcher attempted to find proof whether or not IAIN Bengkulu students got motivated in online learning during the Covid-19.

\section{Concept of Motivation}

According to Harmer (2007:28), "Motivation is some kind of internal drive which pushes someone to do things in order to achieve something." Furthermore, Dimyati and Mudjiono (1994:75) stated that motivation is a driving force or that directs and mentally encourages human behavior. After that, motivation can change to become active at any given time. Especially when that need is really needed in order to achieve a goal.

\section{Instrinsic and Exstrinsic Motivation}

According to Singgih (2008), intrinsic motivation is a strong impulse that comes from within a person. At the same time, John W Santrock (2003: 476) says that intrinsic motivation is a desire from within a person to be competent and do something for the sake of the effort itself. Thursan (2008:28) arguing that intrinsic motivation is motivating someone to do something activity. From some of the opinions above, conclusions can be drawn. Intrinsic motivation is a strong motivation that comes from within an individual without any outside influence that drives someone to do something activity. The stronger the intrinsic motivation owned increasingly shows strong behavior to achieve goals.

Moreover, It means that intrinsic motivation is a desire which comes from within an individual to make an effort to achieve the goal. When the learners have intrinsic motivation, they will show their attitude in the classroom, such as they want to learn English because they like and enjoy learning it. Extrinsic Motivation According to Supandi 
(2011: 61), extrinsic motivation is motivation that arises when there is an external stimulus individual. According to Thomas (2010: 39) the motivation of the extrinsus is motivating motivation or driving from outside given from an individual's own incapacity. According to Jhon W Santrock (2003 : 476) argues, extrinsic motivation is the desire to achieve something with the aim of getting an external goal or get external punishment.

\section{Speaking Class}

Speaking is an interactive process for creating productive meaning involving the production, reception, and processing of information. Speaking is the skill of using language in speaking and not only as a message transfer but also as a means of communication to give and receive information. It is a skill that expresses ideas and feelings through word of mouth. Talking is the ability that people have to communicate with each other, people have the language to convey their speech to someone and also socialites in society (Rao,2019; Nurul, A. et.al, f2020)). Speaking is a productive skill in the oral mode, and it, like the other skills more complicated than that seem at first and involves more than just pronunciation words Nurul, A. et.al (2020).

\section{Research Method}

\section{Research Design}

The design of this research was a descriptive quantitative study. In which the purpose was only to describe how the English students' motivation in speaking class during the new normal at the second semester of the English department of IAIN Bengkulu Academic Year 2020/2021.

Creswell (2014) states that quantitative research is an approach to testing the objective theory by examining the relationship between variables. This variable, in turn, can be measured using instruments so that total data can be analysed using statistical procedures. According to Sugiyono (2010:17), quantitative data is data in the form of numbers or extrapolated quantitative data (assessment). So quantitative data is data that has a tendency to be analysed by statistical means or techniques. Data can be in the form of numbers or scores and is usually obtained using a data collection tool whose answers are ranges of scores or weighted questions. The quantitative method is also called positivistic because it is based on the philosophy of positivism. Besides, this method 
is also called the scientific method or scientific method because it fulfils scientific principles such as the empirical, measurable, objective, systematic and rational.

Based on this explanation, quantitative research is research in the form of numbers or scores, which are measured using instruments and analysed using statistical data. In this study, researchers will use a quantitative descriptive method, using a questionnaire as the main data. Descriptive research, which only describes a number of variables and does not perform hypothesis testing (as is done in explanatory research), is not intended to build and develop a vocabulary of theory. In processing and analysing data, usually statistical processing is used as descriptive (descriptive statistics).

Data were analysed through data acquisition based on research and based on the category of students who have intrinsic and extrinsic motivation is more dominant in learning English in the speaking class. Data are presented statistically using percentages, frequency, arithmetic mean, and standards division.

\section{Population and Sample}

The population is all research objects that will be examined during the implementation of a study, which was explained by Arikunto in Burhan Bungin (2005:110). What is meant by population is that in an area some objects or subjects have certain qualities and characteristics that are determined by the researcher, then they are studied and will be attached to the conclusion. In this study, the population determined by the researcher was all second semester students of IAIN Bengkulu for the academic year 2020/2021.

Then the sample used in this study is all of population, namely 70 English students in the second semester.

\section{Table 1}

Population and Sample Number

\begin{tabular}{|c|c|c|}
\hline No & Class & Students \\
\hline 1. & A & 27 \\
\hline 2. & B & 28 \\
\hline 3. & C & 15 \\
\hline 4. & Total & 70 \\
\hline
\end{tabular}

\section{Research Instruments}


In this research, the researchers used questionnaire, interview, and documentation to collect the data. Data collection in this research can be done in a variety of settings, sources, and various ways. The collection of data used by researchers is based on the technique or method. The main data used in this study is a questionnaire. The questionnaire consisted of 36 questions and was divided into two main sections: intrinsic motivation (items 1-18) and extrinsic motivation (items 19-38). Then the questionnaire was distributed to second-semester students by using google form in the English Education Study Program IAIN Bengkulu, and the answers to the questionnaire were collected to see the answers. To measure student motivation, students fill in the answers by filling in each item of the question. Sources of additional data used in this study were conducting interviews. Researchers interviewed several students randomly, after getting the questionnaire results that had been distributed. Interviews were conducted to find out more and more about the motivation of students in the speaking class. There are ten questions related to motivation used by the researcher in this interview. By using a questionnaire and interview data, after that, the final data can be obtained and then analyzed.

\section{Table 2}

Indicators Instrinsic and Exstrinsic Motivation

\begin{tabular}{|l|l|c|l|}
\hline \multicolumn{1}{|c|}{ Instrinsic } & \multicolumn{1}{|c|}{$\begin{array}{c}\text { Items } \\
\text { number }\end{array}$} & Exstrinsic & \multicolumn{1}{|c|}{$\begin{array}{c}\text { Items } \\
\text { number }\end{array}$} \\
\hline Self desire & $1,2,3,4$ & Praise & $19,20,21$ \\
\hline Satisfaction & $5,6,7$ & Advice & $\begin{array}{l}22,23,24, \\
25\end{array}$ \\
\hline Challenges/ Competition & $8,9,10$, & $\begin{array}{c}\text { Teacher, parents, } \\
\text { Environment }\end{array}$ & $\begin{array}{l}26,27,28, \\
29\end{array}$ \\
\hline Good Habits & 11 & Reward & $30,31,32$, \\
& $12,13,14$, & 33 \\
\hline Awareness & 15 & Punishment & $34,35,36$ \\
\hline
\end{tabular}

The students were asked to answer the question by choosing five categories $S A=5, A=4, N=3, D=2, S D=1$. The Score Of The Question Base Ob The Table Below: 


\begin{tabular}{|c|c|c|}
\hline \multirow{2}{*}{ Optional } & \multicolumn{2}{|c|}{ Score } \\
\cline { 2 - 3 } & Instrinsic & Exstrinsic \\
\hline Strongly agree & 5 & 5 \\
\hline Agree & 4 & 4 \\
\hline Sometimes & 3 & 3 \\
\hline Disagree & 2 & 2 \\
\hline Strongly disagree & 1 & 1 \\
\hline
\end{tabular}

\section{Data Analysis}

The data obtained from the questionnaire were then analyzed using the SPSS program. Data regarding the general background of the subjects and their comments were calculated and presented as a percentage. To measure the level of learning motivation in research subjects using the Likert scale points in the questionnaire. then to determine the level of agreeing or disagree based on the following criteria Mean Range Interpretation:

Table 4

Motivation Level

\begin{tabular}{|l|l|}
\hline & \multicolumn{1}{c|}{ Interpretation } \\
\hline $3.68-5.00$ & High degree of Motivation \\
\hline $2.34-3.67$ & Moderate degree of Motivation \\
\hline $.00-2.33$ & Low degree of Motivation \\
\hline
\end{tabular}

(wimolmas 2012:909)

\section{Result and Discussion}

\section{Result}

\section{The Level of Students' Motivation}

From the results of the data found that students motivation level in speaking class at second semester during new normal era in IAIN Bengukulu academic year $2020 / 2021$ has higest motivation. To find out the result of the details see the following table. 
This section provides the overall research results. The following two tables (Tables 4.3 and 4.4) describe all items totaling 36 questionnaire items, the result is a detailed average score, which is calculated using descriptive statistics of the Average score and Standard Deviation (SD) by describing the level students motivation. Table 4.3 below contains 18 questions on related intrinsic motivation.

\section{a. Insrinsic Motivation}

Intrinsic motivation of the students in the speaking class during new normal era among second semester students of English IAIN Bengkulu Academic Year 2020/2021 is carried out based on the data above. Respondents have a high degree of intrinsic motivation, scoring an average of 4.16 on two question items from different indicators, but the average results are the same. It is included in the satisfaction and good habit indicators' question item. Then there is the moderate level, which has the lowest average value of 3.34 in the awareness indicator's question item. The graph above depicts the data acquisition rating of high data versus moderate data. Then, to see it more clearly the table 4.3 shows the results of the data analysis of intrinsic motivation, which includes 18 question items related to intrinsic motivation.

Table 5

Students Score of Instrinsic Motivation

\begin{tabular}{|c|c|c|c|c|}
\hline Indicators & Items & Mean & S.D & $\begin{array}{c}\text { Rating of } \\
\text { motivational } \\
\text { level }\end{array}$ \\
\hline \multirow{4}{*}{ 1. Self desire } & 1. & $\mathbf{3 , 7 9}$ & $\mathbf{. 9 1 5}$ & High \\
\cline { 2 - 5 } & 2. & $\mathbf{3 , 8 4}$ &. $\mathbf{7 7 3}$ & High \\
\cline { 2 - 5 } & 3. & $\mathbf{3 , 7 3}$ &. $\mathbf{7 9 7}$ & High \\
\cline { 2 - 5 } & 4. & $\mathbf{3 , 6 6}$ & $\mathbf{. 6 5 7}$ & Moderate \\
\hline \multirow{2}{*}{ 2.Satisfaction } & 5. & $\mathbf{3 , 4 0}$ & $\mathbf{. 8 2 4}$ & Moderate \\
\cline { 2 - 5 } & 6. & $\mathbf{4 , 1 6}$ & $\mathbf{. 6 9 4}$ & High \\
\cline { 2 - 5 } & 7. & $\mathbf{4 , 0 0}$ & $\mathbf{. 7 6 1}$ & High \\
\hline \multirow{2}{*}{ 3.Challenges } & 8. & $\mathbf{3 . 8 3}$ & $\mathbf{. 7 2 2}$ & High \\
\cline { 2 - 5 } & 9. & $\mathbf{3 , 9 0}$ & $\mathbf{. 7 0 5}$ & High \\
\hline
\end{tabular}




\begin{tabular}{|c|c|c|c|c|}
\hline & 10. & 3,70 & .688 & High \\
\hline & 11. & 3,50 & .830 & Moderate \\
\hline \multirow[t]{4}{*}{ 4. Good Habits } & 12. & 3,77 & .754 & High \\
\hline & 13. & 4,16 & .715 & High \\
\hline & 14. & 4,00 & .681 & High \\
\hline & 15. & 3,46 & .652 & Moderate \\
\hline \multirow[t]{3}{*}{ 5. Awareness } & 16. & 3,93 & .873 & High \\
\hline & 17. & 3,34 & .759 & Moderate \\
\hline & 18. & 3,64 & .781 & Modrate \\
\hline \multicolumn{2}{|l|}{ TOTAL } & 3,89 & .435 & High \\
\hline
\end{tabular}

Table 5 reveals that respondents have a high

instrinsic motivation level with total of score Mean from the item of questionnaire $(3,89)$ and Standard Deviation (S.D) is $(.435)$. The researcher will explain about the students conception as follows:

From the indicator of self desire, there are three statements which state that student motivation is high, then there is one statement which states that students have a moderate level of motivation. Higest score from the statement is number 2 (I didn't feel compelled when I was actively speaking in the speaking class during the Covid-19 pandemic) with mean score (3.84) and S.D (.773) with the high motivation level. Lowest score from the statements is number 4 (During the pandemic even outside of school hours, I continued to learn to speak English of my own accord) with total mean score is (3.66) and total of SD (.657) this statement is moderate motivation level. Statement number 1 (While studying online during the pandemic, I continued to speak English actively because of my own desire) with total mean score is (3.79) and total of S.D (.915) this statement is high motivation level. Than, statement number 3 (Every time I have homework or assignments in a speaking class I always want to do it quickly even during the Covid-19 pandemic) with total mean score is (3.73) and total of SD (.797) this statement is high motivation level.

From the indicator Satisfaction is two statements with the high motivation level and one statement with the moderate motivation level. The statement 
number 5 (very time I have homework or assignments in a speaking class I always want to do it quickly even during the Covid-19 pandemic) With total mean score is (3.40) and total of S.D (.824) this statement is moderate motivation level. statement number 6 (I always try to be active in learning activities for satisfying results even though studying during the Covid-19 pandemic) with the total mean score is (4.16) and total of S.D (.694) this statement is the highest motivation level. Statement number 7 (Whatever the material provided by the teacher in the speaking class, I always try to understand and ask questions if I don't understand so that I feel satisfied) with total mean score is (4.00) and total of SD (.761) this statement is high motivation level.

From the Challenges / competition indicator, there are three statements which state that student motivation is high, then there is one statement which states that students have a moderate level of motivation. Higer score from the statement is number 9 (When I don't understand the subject matter about speaking and that is one of the challenges for me in learning during the Covid19 pandemic) with mean score (3.90) and SD (.705) at high motivation level. Statement get lowest score is number 11 (when given the opportunity to ask questions I felt challenged) with mean score (3.50) and S.D (.830) at moderate motivation level. Statement number 8 (I was challenged to compete when given the opportunity to speak in a speaking class during the Covid-19 pandemic) with mean score (3.83) and S.D (.722) at high motivation level. Statement number 10 (when given the task it is a challenge in learning during the Covid-19 pandemic) with a mean score (3.70) and S.D (.688) at high motivation level.

From the good habits indicator, there are three statements which state that student motivation is high, then there is one statement which states that students have a moderate level of motivation. Higer score from the statement is number 13 (I always do the assignments given by the speaking lecturer on time) with mean score (4.16) and S.D (.715) at the high motivation level. Statement gets lowest score is statement number 15 (If there is an English lesson tomorrow in the speaking class, at night I always study the English material first) with mean score (3.46) and S.D (.652) at modetare motivation level. Statement number 12 lam actively talking to build good habits in myself despite studying in the midst of the 
Covid-19 pandemic) with mean score (3.77) and S.D (.754) at high motivation level. Than statement number 14 (I make it a habit to actively speak so that my speaking is better) with mean score (4.00) and S.D (.681) at high motivation level.

From the indicator of awareness, there are two statements which state that student motivation is at a moderate level, then there is one statement which states that students have a high motivation level. Higer score from the statement is number 16 (I feel sad if I don't talk actively than my friends in class) with a mean score (3.93) and S.D (.873) at high motivation level. The lowest mean score from the statement is number 17 (I realize that being able to speak English is important for the future) with mean score (3.34) and S.D (.759) at moderate motivation level. The last statement number 18 (Without being asked, I always write down important things when English lessons in the speaking class are in progress, even though studying during the Covid-19 pandemic) with mean score (3.64) and SD (.781) at the moderate motivation level.

\section{b. Extrinsic Motivation}

The findings of the study of extrinsic motivation to learn in the speaking class during the new normal era for the second semester students of IAIN Bengkulu in the 2020/2021 academic year are depicted in the tabel.

Table 6

Students Score of Exstrinsic Motivation

\begin{tabular}{|c|c|c|c|c|}
\hline Indicators & Items & Mean & S.D & $\begin{array}{c}\text { Rating of } \\
\text { motivational } \\
\text { level }\end{array}$ \\
\hline \multirow{7}{*}{ 1. Praise } & 19 & $\mathbf{2 , 9 3}$ & $\mathbf{. 8 4 0}$ & Moderate \\
\cline { 2 - 5 } & 20 & $\mathbf{3 , 6 3}$ & $\mathbf{. 9 3 5}$ & Moderate \\
\cline { 2 - 5 } & 21 & $\mathbf{3 , 3 1}$ & $\mathbf{. 8 0 8}$ & Moderate \\
\hline \multirow{5}{*}{ 2. Advice } & 22 & $\mathbf{3 , 5 4}$ & $\mathbf{. 9 5 8}$ & Moderate \\
\cline { 2 - 5 } & 23 & $\mathbf{3 , 4 4}$ & $\mathbf{. 8 2 8}$ & Moderate \\
\cline { 2 - 5 } & 24 & $\mathbf{3 , 3 9}$ & $\mathbf{1 . 0 5 4}$ & Moderate \\
\cline { 2 - 5 } & 25 & $\mathbf{4 , 1 4}$ & $\mathbf{. 8 8 9}$ & High \\
\hline & 26 & $\mathbf{3 , 1 6}$ & $\mathbf{1 . 0 1 6}$ & Moderate \\
\hline
\end{tabular}




\begin{tabular}{|c|c|c|c|c|}
\hline \multirow{2}{*}{$\begin{array}{c}\text { 3.Teacher,Paren } \\
\text { ts, Environment }\end{array}$} & 27 & $\mathbf{3 , 3 7}$ & $\mathbf{. 8 5 0}$ & Moderate \\
\cline { 2 - 5 } & 28 & $\mathbf{3 , 4 3}$ & $\mathbf{. 8 0 9}$ & Moderate \\
\cline { 2 - 5 } & 29 & $\mathbf{3 , 2 0}$ & $\mathbf{. 9 2 6}$ & Moderate \\
\hline \multirow{2}{*}{4. Reward } & 30 & $\mathbf{3 , 8 3}$ & $\mathbf{. 8 8 4}$ & High \\
\cline { 2 - 5 } & 31 & $\mathbf{2 , 9 4}$ & $\mathbf{. 9 6 1}$ & Moderate \\
\cline { 2 - 5 } & 32 & $\mathbf{3 , 1 1}$ & $\mathbf{1 . 0 1 5}$ & Moderate \\
\cline { 2 - 5 } & 33 & $\mathbf{2 , 8 9}$ & $\mathbf{. 7 9 0}$ & Moderate \\
\hline 5.Punishment & 34 & $\mathbf{2 , 6 9}$ & $\mathbf{1 . 0 0 1}$ & Moderate \\
\cline { 2 - 5 } & 35 & $\mathbf{3 , 2 1}$ & $\mathbf{1 . 0 3 4}$ & Moderate \\
\cline { 2 - 5 } & 36 & $\mathbf{3 , 6 1}$ & $\mathbf{. 8 3 9}$ & Moderate \\
\hline Total & & $\mathbf{3 , 3 9}$ & $\mathbf{. 5 1 9}$ & Moderate \\
\hline
\end{tabular}

Table 4.4 reveals that respondents have a moderate exstrinsic motivation level with the total of score Mean from the item of questionnaire $(3,39)$ and Standard Deviation (S.D) is (.519). The researcher will explain about the students conception as follows:

From the praise indicator, the three statements of this indicator stated that the students' motivation was at a moderate level. Higest score from the statement is number 20 (I get compliments from my parents, if I get good speaking scores) with mean score (3.63) and S.D (.935) at moderate motivation level. Lowest score from the statement is number 19 (I am actively speaking to attract the attention of lecturers in the speaking class during the Covid-19 epidemic) with mean score (2.93) and S.D (.840) at moderate motivation level. Than statement number 21 (If my score is good, the lecturer will give praise in the online class) with mean score (3.31) and S.D (.808) at moderate motivation level.

From the advice indicator, the three statements of this indicator state that the student's motivation is at a moderate level. Then one statement stated that the student was at a high motivation level. Higest score from the statement is number 25 (My parents advised me never to skip class in speaker class) with mean score (4.14) and S.D (.889) at high motivation level. Than the lowest score from the statement is number 23 (I am active because I am always given advice 
while studying) with the mean score score (3.39) and S.D (1.054) at moderate motivation level. Statement number 22 (I am actively speaking so that the lecturers give good advice) with mean score (3.54) and S.D (.958) at moderate motivation level. Than statement number 24 (My friends advised me to study hard) with mean score (3.44) and S.D (.828) at moderate motivation level.

From the teacher, parents, environment indicators, all statements from this indicator state that the student's motivation is at a moderate level. Higest score from the statement is number 28 (Fun learning facilities so I actively speak English) with mean score (3.43) and S.D (.809) at moderate motivation level. Than the lowest score from the statement is number 26 (I actively speak if I like the lecturer) with mean score (3.16) and S.D (1.016) at moderate motivation level. Statement number 27 (Interesting material made me speak actively in class during this Covid-19 pandemic) with mean score (3.37) and S.D (.850) at moderate motivation level. Statement number 29 (I like the gifts from parents if I can speak English) with mean score (3.20) and S.D (.926) at moderate motivation level.

From the reward indicator, the three statements of this indicator stated that the students' motivation was at a moderate level. Then one statement stated that the student's motivation was at the high motivation level. The highest score from the statement is number 30 (I am active in class to get good grades) with mean score (3.83) and S.D (.884) at high motivation level. Than the lowest score from the statement is number 33 (I was active because I didn't get gifts from my friends) with mean score (2.89) and S.D (.790) at moderate motivation level. Statement number 31 (The lecturer always gives a gift at the end of the lesson so that I am always active in class) with mean score (2.94) and S.D (.961) at moderate motivation level. The last statement number 32 (I am even more excited to achieve if I get a gift from my parents during Covid-19) with mean score (3.11) and S.D (1.015) at moderate motivation level.

From the punishment indicator, all statements from this indicator stated that the students' motivation was at a moderate level. Higest score from the statement is number 36 (I always do my assignments on time to avoid being punished despite studying in the midst of the Covid-19 pandemic) with mean score (3.61) and S.D (.839) at moderate motivation level. Than the lowest score 
from the statement is number 35 (I am actively talking to avoid punishment and so my friends will know that I can) with mean score (3.21) and S.D (1.034) at moderate motivation level. The last statement is number 34 (I am actively speaking because there is a punishment) with mean score (2.69) and S.D (1.001) at moderate motivation level.

\section{Result of Interview}

To validate and support the data from the questionnaire, the researcher conducted interviews. Several students were interviewed. The total number of students interviewed was to several students. The ten questions in the interview section were asked of students to find out their answers about motivation while studying in the speaking class in the second semester of the English Education Study Program at IAIN Bengkulu academic year 2020/2021.

Based on their answers with the interview questionnaire, the majority of those who were interviewed were more motivated by the intrinsic motivation in learning in the speaking class during this new normal era. Students who have intrinsic motivation are students learning English in the speaking class because they have their own desire to be good at speaking English, even though currently the learning process is different from the usual learning system. As we know, online or online learning is a result of the Covid-19 outbreak where students are far from teacher assistance, so they motivate themselves so they can become active students in the speaking class.

\section{Discussion}

Motivation to learn is an encouragement in students who are motivated in carrying out learning activities for continuity and determining the direction of learning in order to achieve learning success. The several indicators of intrinsic motivation in learning include: 1) self desire 2) satisfaction; 3) Challenges / Competition; 4) good habits; 5) awareness, and indicators of extrinsic motivation in learning include: 1) praise, 2) advice, 3) teacher, parents, environment, 4) reward, 5) punishment. Some of these indicators can be used to see how the students' motivation to learn in the speaking class during the new normal era. 
Based on data from the results of the questionnaires and interviews described above, the speaking class learning process during the Covid-19 pandemic was given remotely or online. The material is delivered through google meet and also whatsap group. Based on the results of this study, it was found that intrinsic motivation indicators were categorized at a high level of motivation, which means that students have an interest and enthusiasm in studying further material to gain achievement in learning and there is a strong will from within students. Then the extrinsic motivation indicators are categorized at the moderate motivation level based on the average value obtained from the overall results of the question items from each indicator, meaning this shows that students do think that learning English and speaking English is a challenging lesson, but students have willingness and tenacity in learning.

Then based on the results of the calculation of the score between intrinsic and extrinsic motivation of the students above, it was found that the total average score for intrinsic motivation was (3.89) and the total average score for extrinsic motivation was (3.39). The results of this study indicate that the second semester English students of IAIN Bengkulu during the new normal era have higher intrinsic motivation than extrinsic motivation in learning English, especially in the speaking class. So thus even though learning with the new system due to the Covid-19 outbreak that hit, students still have good motivation, so that in the learning process they learn based on desires that arise from within themselves and not because of external encouragement, even though there are many the difficulties they experience during the learning process.

\section{Conclusions}

Student learning motivation in the second semester in speaking class during the new normal era. Most of the students of the English Education Study Program at IAIN Bengkulu in the second semester have intrinsic motivation in learning English, especially in the speaking class. This can be seen from the average score of intrinsic motivation (3.89) which is higher than the average score of extrinsic motivation (3.39). That means they learn English because of their inner desire to be good at speaking English even though the learning system is slightly different from the previous one, namely the online learning system.

\section{References}


Nurul, A. et.al (2020). Improving Students Speaking Ability Through Repetition Drill Professional Journal of English Educationvolume 3, No. 1.

Gross, D.B. (2006). Motivating Students. University of California, Berkeley.

Hidayati, T, N. (2016). Students Motivation in Learning English by Using Games. (A Descriptive Study at the Third Grade of Intensive English Class of Pondok Pesantren Darul Falah Be-Songo Semarang).

Ihsan, M.D. (2016). Students Motivation in Speaking English. Journal of English Educators Society (Jees) Volume 1.

Jeremy, H. The Practice of English Language Teaching.Third edition. Longman Pearson Education Limited.p 28.

Dimyati \& Mudjiono. Belajar dan Pembelajaran. Malang University.

Rao, P.S. (2019). The Importance of Speaking Skills in English Classrooms .VS Publications Alford Council of International English \& Literature Journal(ACIELJ), Vol.2.

Rusdi. (2013). Filsafat idealisme : Implikasinya dalam pendidikan. Dinamika IImu. Fenomena. 13(2), 21.

Rafsanjani A.I. , (2020).Kebijakan Pendidikan di Era New Normal.

Sugiyono. (2015). Metode Penelitian Pendidikan Pendekatan Kuantitatif, Kualitatif, dan R\&D. Bandung: Alfabeta.

Tria, J.Z. (2020) The COVID-19 Pandemic through the Lens of Education in the Philippines: The New Normal. International Journal of Pedagogical Development and Lifelong Learning, ISSN 2732-4699.p.2. Access on January 25,2020.

Noprianti, S., Akbarjono, A., \& Martina, F. (2021). The Influence of Storytelling on EFL Students Motivation in Speaking Practice in SMPN 03 Bengkulu Tengah. Jadila: Journal of Development and Innovation in Language and Literature Education, 1 (4), 470-477. 